\title{
KARAKTERISTIK SUBJEKTIF TIDUR KLIEN RAWAT INAP DEWASA DI RUMAH SAKIT X DEPOK
}

\author{
Rahma Marfiani $^{1 *}$, Hening Pujasari ${ }^{2}$ \\ 1. Program Studi Sarjana, Fakultas Ilmu Keperawatan, Universitas Indonesia, Depok 16424, Indonesia \\ 2. Fakultas Ilmu Keperawatan, Universitas Indonesia, Depok 16424, Indonesia \\ *E-mail: rahma.marfiani@ui.ac.id
}

\begin{abstract}
Abstrak
Penelitian ini mengenai karakteristik subjektif tidur pada klien rawat inap dewasa di Rumah Sakit X Depok. Desain penelitian ini deskriptif sederhana dengan pendekatan cross-sectional. Sampel yang terlibat berjumlah 72 pasien dengan teknik pengambilan sampel consecutive sampling. Responden mengisi kuesioner berisi skala tidur Verran dan SnyderHalpern. Hasil penelitian didapatkan bahwa pasien mengalami gangguan tidur tingkat sedang $(47,22 \%)$ hingga berat (25\%). Efektivitas tidur pasien juga hanya berada pada tingkat sedang (50\%) hingga rendah (19,44\%). Pasien juga mensuplementasikan tidurnya dengan tingkatan sedang $(38,88 \%)$ hingga tinggi $(22 \%)$. Penelitian ini dapat digunakan sebagai penelitian dasar untuk meneliti faktor-faktor yang memengaruhi pola tidur pasien rawat inap.
\end{abstract}

Kata kunci: karakteristik subjektif tidur, klien dewasa, rawat inap, skala tidur Verran dan Snyder-Halpern

\section{Abstract}

Sleeping Subjective Characteristics of Adult Patient at X Hospital Depok. This research explored subjective sleep characteristics of hospitalized adult patients in X Hospital Depok. Simple descriptive design was used in this research. Consecutive sampling was applied on this study involving 72 patients. Patients were asked to fill the questionnaire about Verran and Snyder Halpern sleep scale (VSH Sleep Scale). Results showed that patients experienced sleep disturbance with moderate levels (47,22\%), moreover (25\%) patients experienced severe sleep disturbance. Patients felt that sleep effectiveness in moderate levels (50\%), moreover $(19,44 \%)$ patients felt that sleep effectiveness only in low levels. Sleep supplementation also experienced by patients with moderate levels $(38,88 \%)$, moreover (22\%) patients experienced sleep supplementation in high levels. This research can be used as a pilot study to find out factors that affecting how patients sleep in the hospital environment.

Keywords: adult patients, hospitalized, subjective sleep characteristics, VSH Sleep Scale

\section{Pendahuluan}

Tidur merupakan salah satu kebutuhan dasar yang juga penting bagi kelangsungan hidup manusia. Seseorang yang sedang sakit dan dirawat di rumah sakit atau fasilitas pelayanan kesehatan lainnya sering kali dihadapkan pada dua keadaan yang berlawanan, yaitu di satu sisi individu yang sakit tersebut mengalami peningkatan kebutuhan tidur (Crisp \& Taylor, 2001). Di sisi lain pola tidur seseorang yang masuk dan dirawat di rumah sakit akan dengan mudah terganggu (DeLaune \& Ladner, 2011). Hal ini sangat disayangkan karena kekurangan tidur secara potensial dapat mengganggu sistem pertahanan tubuh seseorang, sehingga pemenuhan kebutuhan tidur yang adekuat harus tercapai pada tahap penyembuhan penyakit. Menurut Benca dan Quintans (1997) seseorang yang kurang tidur akan berdampak secara tidak langsung pada sistem pertahanan tubuhnya. Sel natural killer, yaitu salah satu komponen pada sistem pertahanan non spesifik tubuh yang berespon untuk mengatasi stres akut, akan menurun jumlahnya seiring dengan kurangnya kualitas dan kuantitas tidur (Wright, Erblich, Valdimarsdottir, \& Bovbjerg, 2007).

Pola tidur seseorang yang dirawat di rumah sakit akan mudah terganggu oleh berbagai macam faktor, seperti lingkungan rumah sakit yang baru 
ditempati, penyakit yang dideritanya, tingkat stres, dan lain-lain. Perubahan pola tidur seseorang ditandai dengan buruknya karakteristik tidur yang hanya dirasakan oleh orang tersebut dan lebih lanjut lagi akan menimbulkan gangguan tidur. Gangguan tidur menurut pendapat para ahli dapat dikaitkan dengan penurunan fungsi imun seseorang, perubahan status mental, dan peningkatan tingkat stres (Meerlo, Sgoifo, \& Suchecki, 2008). Efek negatif tersebut dapat mengganggu proses penyembuhan pada klien dewasa yang sedang dirawat di ruang rawat akut rumah sakit (Patel, Chipman, Carlin, \& Shade, 2008). Penelitian terhadap pasien dewasa di Amerika menemukan bahwa gangguan tidur memengaruhi proses penyembuhan seseorang dari penyakit (Doering, McGuire, \& Rourke, 2002; Redeker, Ruggiero, \& Hedges, 2004).

Karakteristik tidur yang dirasakan oleh pasien terdiri dari beberapa komponen. Menurut kerangka konsep taksonomi Snyder-Halpern dan Verran (1987) bahwa ada tiga komponen karakteristik subjektif tidur, yaitu komponen gangguan tidur, efektivitas tidur, dan suplementasi tidur (Humphries, 2008). Komponen gangguan pada tidur terdiri dari tujuh komponen, yaitu terbangun di sela-sela waktu tidur, terbangun saat hendak memulai tidur, pergerakan saat tidur, kedalaman tidur, latensi tidur, kualitas latensi tidur, dan kualitas gangguan tidur. Komponen efektivitas tidur memiliki lima karakteristik, yaitu perasaan lelah saat sudah terjaga, kualitas tidur yang dirasa oleh klien, total periode tidur, total waktu tidur, dan evaluasi kecukupan tidur. Komponen supplementasi tidur terdiri dari empat karakteristik, yaitu terbangun setelah sadar sepenuhnya, tidur di siang hari, pagi hari, dan sore hari.

Penelitian terkait mengenai angka kejadian dan karakteristik subjektif tidur pada klien dewasa yang dilakukan di Rumah Sakit Amerika Serikat mengungkapkan bahwa sebagian besar subjek penelitian melaporkan telah mengalami gangguan tidur berat, efektivitas tidur yang rendah, dan suplementasi tidur tingkat sedang (Humphries, 2008). Indonesia sendiri belum ada penelitian yang meneliti karakteristik subjektif tidur pada klien dewasa seperti penelitian yang telah disebutkan di atas. Berdasarkan hal tersebut, maka peneliti tertarik untuk meneliti lebih lanjut mengenai karakteristik subjektif tidur pada klien rawat inap dewasa di Rumah Sakit X Depok.

\section{Metode}

Penelitian ini menggunakan desain penelitian deskriptif sederhana. Sampel penelitian berjumlah 72 pasien yang ditentukan dengan menggunakan teknik consecutive sampling. Pengumpulan data dilakukan dengan menggunakan kuesioner yang berisi 10 pertanyaan mengenai karakteristik responden dan 15 pernyataan yang berisi VSH Sleep Scale. Pernyataan yang ada di kuesioner berjumlah 15 terdiri dari 7 pernyataan yang menggambarkan komponen gangguan tidur, 5 pernyataan menggambarkan komponen efektivitas tidur, dan 4 pernyataan lainnya menggambarkan komponen suplementasi tidur yang dialami responden saat mencoba untuk tidur malam hingga terjaga di pagi harinya. Pernyataan yang ada di kuesioner sejumlah 15 , namun karakteristik yang harus diukur ada 16. Karakteristik keenam belas akan diukur dengan cara menjumlahkan pernyataan nomor 1 dan 2 .

Kuesioner ini menggunakan visual analogue scale (VAS), yaitu rentang 0-100 dari sebelah kiri ke kanan, dinyatakan dalam suatu garis, yang akan direfleksikan ke dalam kertas millimeter blocks sepanjang $10 \mathrm{~cm}$. Kuesioner ini juga sudah baku dalam Bahasa Inggris, lalu diterjemahkan ke dalam Bahasa Indonesia dan dinyatakan valid serta reliabel. Nilai alpha cronbach untuk kuesioner ini terbagi menjadi 3, disebabkan tiap komponen karakteristik subjektif tidur tidak dapat digabung satu sama lain. Komponen gangguan tidur memiliki nilai alpha cronbach sebesar 0,77, untuk komponen efektivitas tidur sebesar 0,69, sedangkan yang terakhir untuk komponen suplementasi tidur nilai alpha cronbach yang dihasilkan yaitu 0,6, sehingga kuesioner ini dinyatakan reliabel.

Polit dan Beck (2008) menjelaskan bahwa terdapat tiga acuan utama mengenai etika penelitian, yaitu prinsip manfaat (beneficence), prinsip menghormati harkat dan martabat orang lain (respect of human dignity), dan prinsip keadilan (justice). 
Prosedur pengumpulan data dilakukan dengan cara prosedur administrasi yang diawali dengan izin pengambilan data awal dan izin penelitian. Pengolahan data dilakukan dengan empat tahap, yaitu editing, coding, processing, cleaning. Setelah melakukan pengolahan data, dilakukan analisis data. Penelitian ini menggunakan analisis univariat dengan menyajikan distribusi frekuensi dan ditampilkan dalam bentuk tabel.

\section{Hasil}

Karakteristik Responden. Pada Tabel 1 didapatkan bahwa rerata usia klien dewasa yang rawat inap di rumah sakit yaitu 35 tahun dengan standar deviasi sebesar 11,55. Hasil pengakuan responden mengenai jam tidurnya saat masih di rumah yaitu didapatkan rerata sebesar 8 jam dengan standar deviasi 1,69. Nilai tengah lama hari rawat klien dewasa di rumah sakit yaitu selama 3 hari dengan rentang lama hari rawat minimal 1 hari dan yang paling lama yaitu 9 hari.

Pada Tabel 2 didapatkan bahwa perbandingan jenis kelamin responden yang mengikuti penelitian ini yaitu hampir seimbang antara laki-laki dan perempuan, terdiri dari perempuan 37 orang $(51,4 \%)$ sedangkan laki-laki 35 orang $(48,6 \%)$. Pasien rawat inap di rumah sakit cenderung lebih banyak yang bekerja tanpa shift yaitu berjumlah 20 orang $(27,8 \%)$, meskipun demikian banyak pula yang memiliki pekerjaan dengan metode shift sebesar 17 orang $(23,6 \%)$. Status perkawinan responden didominasi dengan status menikah berjumlah 47 orang $(65,3 \%)$. Pasien cenderung dirawat di rumah sakit karena diagnosis medis yang dikelompokan pada penyakit dalam noninfeksius, yaitu berjumlah 54 orang (75\%).

Mayoritas responden dalam penelitian ini mengaku memiliki kebiasaan sebelum tidur saat masih di rumah yaitu berjumlah 43 orang $(59,7 \%)$. Pasien juga banyak yang mengaku mengalami gangguan tidur saat dirawat di rumah sakit dengan jumlah 46 orang $(63,9 \%)$. Daftar pemberian obat yang dimiliki oleh setiap pasien yang didominasi dengan pasien yang tidak sedang menggunakan obat tidur dengan jumlah 67 orang $(93,1 \%)$. Terdapat pula pasien yang sedang menggunakan obat tidur sebanyak 5 orang $(6,9 \%)$. Sebanyak $59,7 \%$ pasien yang memiliki kebiasaan tidur saat masih di rumah, didominasi dengan menonton TV sebagai kebiasaan sebelum tidurnya sebesar 33 orang (76,74\%). Sebanyak 63,9\% pasien yang memiliki gangguan tidur di rumah sakit, didominasi dengan masalah yang terkait lingkungan ruang rawat inap sebesar 30 pasien $(65,22 \%)$.

Karakteristik Subjektif Tidur Pasien. Hasil penelitian menunjukan bahwa klien dewasa di rumah sakit berada pada kategori sedang untuk semua komponen karakteristik subjektif tidur. Pada Tabel 3 didapatkan bahwa gangguan tidur yang terjadi pada pasien berada pada tingkat sedang yaitu sebanyak 34 orang $(47,22 \%)$, meskipun demikian terjadi pula gangguan tidur berat sebanyak 18 orang (25\%) atau seperempatnya dari jumlah sampel yang ada. Efektivitas tidur yang diharapkan berada pada posisi tinggi tidak tercapai pada klien dewasa di rumah sakit. Pasien yang hanya mendapatkan efektivitas tidur tingkat tinggi sebanyak 22 orang (30,56\%), sedangkan yang banyak dicapai oleh pasien yaitu efektivitas tidur tingkat sedang sebanyak 36 orang (50\%). Lebih banyak pasien yang mengalami suplementasi tidur tingkat sedang sebesar 28 orang $(38,88 \%)$. Suplementasi tidur ini seharusnya hanya berada pada tingkat rendah, akan tetapi terjadi pula suplementasi tidur tinggi pada 22 orang pasien di rumah sakit $(30,56 \%)$.

Pada Tabel 4 didapatkan bahwa klien dewasa di rumah sakit sering sekali mengalami gangguan tidur khususnya terbangun di sela-sela tidurnya pada malam hari. Hal ini dapat dilihat dari rerata yang cukup tinggi dicapai yaitu sebesar 72,60 dari rentang 0-100. Banyak pasien yang sering bergerak saat tidur rerata sebesar 60,53 dari rentang 0-100. Kedalaman tidur pasien selama dirawat inap di rumah sakit terbilang hanya berada pada tingkat sedang yaitu reratanya sebanyak 59,74 dari rentang 0-100.

Efektivitas tidur klien dewasa di rumah sakit secara umum berada pada tingkat sedang, yang sebaiknya berada pada tingkat tinggi. Durasi total tidur yang didapat oleh pasien rerata sebesar 54,61 dari rentang 0-100, yang berarti 
hanya 5,46 jam durasi total tidur klien dewasa di rumah sakit. Penafsiran ini didapat karena ada beberapa rentang garis pada kuesioner yang dapat direfleksikan sebagai suatu waktu, yaitu dari 0-10 jam. Hal tersebut ternyata tidak seimbang dengan pencapaian periode total tidur pasien yaitu rerata sebesar 73,43 dari rentang 0-100, artinya klien dewasa yang rawat inap di rumah sakit rerata memiliki periode total tidur sebanyak 7,34 jam.
Klien dewasa yang mengalami kekurangan tidur pasti akan mengganti waktu tidurnya di lain waktu, seperti di waktu pagi, siang, ataupun sore hari. Hal tersebut disebut dengan suplementasi tidur. Suplementasi tidur secara umum pada klien dewasa di rumah sakit reratanya berada pada tingkat sedang. Meskipun demikian suplementasi tidur yang paling banyak terjadi yaitu saat di pagi hari dengan rerata sebesar 56,67 dari rentang 0 100 , yang berarti pasien rerata menghabiskan waktu tidur di pagi hari sebanyak 5,7 jam.

Tabel 1. Karakteristik Klien Rawat Inap Dewasa di Rumah Sakit Berdasarkan Usia, Lama Hari Rawat, dan Jam Tidur di Rumah

\begin{tabular}{lccccc}
\hline Variabel & Mean & Median & Standar Deviasi & Min-Maks & $\begin{array}{c}\text { Mean Difference } \\
\text { (CI 95\%) }\end{array}$ \\
\hline Usia & 34,99 & 32 & 11,55 & $18-55$ & $\mathbf{3 2 , 2 7 - 3 7 , 7 0}$ \\
Lama Hari Rawat & 3,26 & 3 & 1,78 & $1-9$ & $\mathbf{2 , 8 5 - 3 , 6 8}$ \\
Jam Tidur di Rumah & 7,68 & 7,75 & 1,69 & $1-13$ & $\mathbf{7 , 2 8 - 8 , 0 8}$ \\
\hline
\end{tabular}

Tabel 2. Klien Rawat Inap Dewasa di Rumah Sakit Berdasarkan Jenis Kelamin, Pekerjaan, Status Perkawinan, Diagnosis Medis, Kebiasaan Sebelum Tidur di Rumah, Masalah Tidur di RS, dan Penggunaan Obat Tidur

\begin{tabular}{llcc}
\hline Data Demografi & \multicolumn{1}{c}{ Kategori } & Frekuensi & Persentase (\%) \\
\hline Jenis Kelamin & Perempuan & 37 & 51,4 \\
& Laki-Laki & 35 & 48,6 \\
Pekerjaan & Pelajar/mahasiswa & 6 & 8,3 \\
& Bekerja tanpa shift & 20 & 27,8 \\
& Bekerja dengan shift & 17 & 23,6 \\
& Pensiun & 0 & 0 \\
& Tidak bekerja & 29 & 40,3 \\
Status Perkawinan & Belum menikah & 20 & 27,8 \\
& Menikah & 47 & 65,3 \\
& Janda/duda & 5 & 6,9 \\
Diagnosis Medis & Penyakit dalam non-infeksius & 54 & 75,0 \\
& Penyakit dalam infeksius & 6 & 8,3 \\
Kebiasaan Sebelum Tidur di & Tidak ada kebiasaan & 12 & 16,7 \\
Rumah & Ada kebiasaan & 29 & 40,3 \\
Masalah Tidur di RS & Tidak ada masalah tidur & 43 & 59,7 \\
& Ada masalah tidur & 26 & 36,1 \\
Penggunaan Obat Tidur & Tidak menggunakan obat tidur & 46 & 63,9 \\
& Menggunakan obat tidur & 67 & \\
& & 5 & 93,1 \\
\hline
\end{tabular}


Tabel 3. Karakteristik Subjektif Tidur Klien Rawat Inap Dewasa di Rumah Sakit

\begin{tabular}{llcc}
\hline Karakteristik Subjektif Tidur & Kategori & Frekuensi & Persentase (\%) \\
\hline Gangguan Tidur & Ringan & 20 & 27,78 \\
& Sedang & 34 & 47,22 \\
Efektivitas Tidur & Berat & 18 & 25 \\
& Rendah & 14 & 19,44 \\
& Sedang & 36 & 50 \\
Suplementasi Tidur & Tinggi & 22 & 30,56 \\
& Rendah & 22 & 30,56 \\
& Sedang & 28 & 38,88 \\
& Tinggi & 22 & 30,56 \\
\hline
\end{tabular}

Tabel 4. Nilai Rerata Semua Pernyataan Karakteristik Subjektif Tidur pada Klien Rawat Inap Dewasa di Rumah Sakit

\section{Sub Variabel Karakteristik Subjektif Tidur}

\section{Gangguan Tidur:}

a. Terbangun di sela-sela waktu tidur

b. Terjaga saat sudah mulai mengantuk

c. Pergerakan saat tidur

d. Kedalaman tidur

e. Kualitas gangguan tidur

f. Latensi tidur

g. Kualitas latensi tidur

\section{Efektivitas Tidur:}

a. Perasaan lelah saat sudah terjaga

b. Kualitas tidur yang dirasa oleh pasien

c. Evaluasi kecukupan tidur

d. Total waktu tidur

e. Periode total tidur

\section{Suplementasi Tidur:}

a. Tidur pada rentang pagi hingga sore hari

b. Tidur di pagi hari

c. Tidur di sore hari

d. Waktu terjaga setelah sadar sepenuhnya

\section{Pembahasan}

Karakteristik responden yang dibahas pada penelitian ini meliputi usia, jam tidur pasien saat masih di rumah, lama hari rawat pasien, jenis kelamin, pekerjaan, status perkawinan, diagnosis medis, masalah tidur di rumah sakit, kebiasaan sebelum tidur di rumah, dan penggunaan obat tidur. Hasil penelitian didapatkan bahwa rerata usia klien dewasa di RS X Depok yaitu 35 tahun, dengan rentang 18-55 tahun. Jam tidur pasien saat masih di rumah dengan reratanya sebesar 7,7 jam per hari. Lama hari rawat pasien rerata sebanyak 3 hari. Rerata jenis kelamin pasien hampir sama jumlahnya antara laki-laki dan perempuan. Mayoritas pekerjaan pasien yaitu bekerja tanpa shift, meskipun demikian jumlah pekerja dengan shift cukup banyak pula. Hal ini dapat memengaruhi pola tidur pasien. Kebanyakan status perkawinan pasien yaitu berstatus menikah, akan tetapi jumlah pasien yang masih sendiri serta yang berstatus janda/duda cukup banyak 
pula. Menurut Humphries (2008) seseorang yang berstatus sudah menikah namun sekarang hidup sendiri ataupun seseorang yang dari sejak awal sudah hidup sendirian, mungkin akan mengalami stres yang berdampak pada pengurangan efektivitas tidurnya.

Mayoritas klien dewasa di RS X Depok dirawat inap karena diagnosis medis yang digolongkan pada penyakit dalam non-infeksius. Sebanyak setengah lebih jumlah sampel di RS X Depok menyatakan dirinya selalu melakukan kebiasaan sebelum tidur, yang rerata dilakukan yaitu menonton TV. Klien dewasa di RS X Depok banyak yang mengeluhkan adanya masalah tidur saat dirawat inap di rumah sakit tersebut. Tiga jenis masalah tidur yang dialami pasien secara berturut-turut yaitu masalah tidur terkait lingkungan, penyakit fisik, dan stres emosional. Masalah lingkungan disini yaitu terkait dengan suhu ruang rawat inap yang panas. Perawat pelaksana secara subjektif juga mengatakan hal yang serupa seperti yang pasien rasakan tersebut. Karakteristik responden yang terakhir yaitu penggunaan obat tidur. Hasil analisis univariat tentang penggunaan obat tidur didominasi dengan pasien yang tidak sedang menggunakan obat tidur, akan tetapi terdapat pula beberapa pasien yang sedang menggunakan obat tidur.

Pembahasan selanjutnya yaitu mengenai karakteristik subjektif tidur klien dewasa di RS X Depok. Komponen yang pertama yaitu gangguan tidur. Keseluruhan komponen gangguan tidur pada karakteristik subjektif tidur menunjukkan bahwa klien dewasa di ruang rawat inap RS X Depok mengalami gangguan tidur tingkat sedang (47,22\%), akan tetapi terdapat (25\%) pasien yang mengalami gangguan tidur berat. Hal tersebut tidak seharusnya terjadi, meskipun seseorang yang masuk dan di rawat di rumah sakit pasti akan mengalami perubahan pola tidur (DeLaune \& Ladner, 2011), namun diharapkan hanya berada pada tingkatan yang rendah saja. Gangguan tidur pada tingkatan sedang berarti gangguan tidur tersebut telah cukup dirasa mengganggu oleh pasien. Hal ini akan memicu terjadinya gangguan tidur akut yang selanjutnya akan mengganggu proses penyembuhan pasien tersebut.
Gangguan tidur menurut pendapat para ahli dapat dikaitkan dengan penurunan fungsi imun seseorang, perubahan status mental, dan peningkatan tingkat stres (Meerlo, et al., 2008). Efek negatif tersebut dapat mengganggu proses penyembuhan pada klien dewasa yang sedang dirawat di ruang rawat akut rumah sakit (Patel, et al., 2008). Penelitian terhadap pasien dewasa di Amerika menemukan bahwa gangguan tidur memengaruhi proses penyembuhan seseorang dari penyakit (Doering, et al., 2002; Redeker, et al., 2004). Hal ini seharusnya sangat dihindari terjadi pada suatu rumah sakit, karena dapat memperpanjang masa penyembuhan pasien yang berarti memperpanjang proses rawat inap pasien (Patel, et al., 2008). Proses rawat inap yang memanjang dan berlarut-larut akan memperburuk mutu pelayanan rumah sakit tersebut.

Komponen karakteristik subjektif tidur yang kedua yaitu efektivitas tidur. Secara keseluruhan semua komponen karakteristik efektivitas tidur berada pada tingkatan sedang. Akan tetapi, adanya gap/jarak antara total waktu tidur pasien dengan periode total tidur, menandakan pasien tidak langsung tidur saat sudah mengantuk. Penyebabnya mungkin adalah faktor-faktor yang dibahas pada karakteristik responden seperti faktor lingkungan, penyakit fisik, stres emosional, dan lain-lain. Seperti yang telah diketahui penyebab tertinggi masalah tidur pada klien dewasa di RS X Depok adalah suhu ruang rawat inap yang panas, hal itulah yang menjadi alasan mengapa pasien tidak langsung tertidur meskipun sudah mengantuk. Hal inilah yang menyebabkan komponen efektivitas tidur pasien hanya berada pada tingkatan sedang (50\%), yang sebaiknya berada pada tingkatan tinggi. Pasien yang hanya mendapat efektivitas tidur yang tinggi sebesar $(30,56 \%)$ saja.

Komponen karakteristik subjektif tidur yang terakhir yaitu suplementasi tidur. Suplementasi tidur merupakan kegiatan dalam mengganti waktu tidur malam seseorang di waktu pagi hingga sore hari. Seorang individu yang mengalami kekurangan tidur tahap REM akan tertidur pada pagi harinya, sebagai tambahan waktu tidurnya yang kurang di malam hari. Hal tersebut karena menurut 
Hayter (1980) tahap REM lebih banyak jumlah durasinya saat tidur di pagi hari (Humphries 2008). Menurut teori dari Patel dan Gupta (2008) bahwa pasien yang sering terbangun di malam hari membutuhkan waktu tidur di siang hari sebagai kompensasi waktu total tidurnya yang kurang. Lebih lanjut dikemukakan bahwa tidur pada sore hari terjadi pada individu yang mengalami kekurangan tidur tahap NREM 3. Pasien di RSUD Depok yang berada pada tahap perkembangan dewasa dan terbukti tidak terlalu dalam tidurnya sudah pasti membutuhkan waktu tidur pengganti di pagi hari.

Klien dewasa di RS X Depok sudah mampu dalam tingkatan sedang untuk mensuplementasikan waktu tidur malamnya yang kurang dengan waktu tidur pada pagi hari. Seluruh komponen pada suplementasi tidur klien dewasa di RSUD Depok berada pada tingkatan sedang $(38,88 \%)$, akan tetapi terdapat $(30,56 \%)$ pasien yang mengalami tingkat kejadian suplementasi tidur yang tinggi. Hal ini seharusnya tidak terjadi, apabila pasien telah cukup waktu tidurnya di malam hari. Pola tidur pasien kenyataanya tidak adekuat dalam hal kuantitas maupun kualitasnya, sehingga salah satu cara untuk menutupi kekurangan tersebut adalah dengan mengganti waktu tidur malam dengan waktu-waktu lain dari rentang pagi hingga sore hari. Bila suplementasi tidur yang dibutuhkan oleh pasien untuk mengganti waktu tidurnya di malam hari tidak didapatkan, maka pasien tersebut akan sangat mengalami kekurangan waktu tidur, yang akan selalu berujung pada kejadian gangguan tidur. Lebih lanjut lagi, gangguan tidur tersebut akan memperlama proses penyembuhan pasien serta memperpanjang masa perawatan pasien di rumah sakit tersebut (Patel, et al., 2008). Proses rawat inap yang memanjang dan berlarut-larut akan memperburuk mutu pelayanan rumah sakit tersebut. Hal tersebut tentunya sangatlah dihindari oleh pihak rumah sakit.

\section{Kesimpulan}

Klien dewasa di RS X Depok rerata berusia 35 tahun, dengan perbandingan jenis kelamin antara laki-laki dan perempuan yaitu hampir sama jumlahnya, mayoritas berstatus sudah menikah, namun didominasi dengan status pekerjaan tidak bekerja. Pasien saat masih di rumah rerata tidur malam selama 8 jam, yang didahului dengan kebiasaan sebelum tidur yaitu mayoritas menonton TV. Pasien masuk dan dirawat di RSUD Depok rerata karena diagnosis medis penyakit dalam non-infeksius, dengan rerata lama hari rawat-nya sebesar 3 hari, mayoritas pasien tidak sedang menggunakan obat tidur, dan pasien mengaku mengalami gangguan tidur khususnya gangguan tidur karena lingkungan yang panas di ruang rawat inap RS X Depok.

Klien dewasa di RS X Depok mengalami gangguan tidur dengan tingkatan sedang $(47,22 \%)$, lebih lanjut lagi ternyata terdapat beberapa pasien $(25 \%)$ yang mengalami gangguan tidur berat. Klien dewasa di RS X Depok mengalami efektivitas tidur dengan tingkatan sedang (50\%), lebih lanjut lagi ternyata terdapat beberapa pasien $(19,44 \%)$ yang hanya mengalami efektivitas tidur rendah. Klien dewasa di RSUD Depok mengalami suplementasi tidur dengan tingkatan sedang $(38,88 \%)$, lebih lanjut lagi ternyata terdapat beberapa pasien $(22 \%)$ yang mengalami suplementasi tidur tinggi.

Hasil penelitian ini diharapkan dapat digunakan sebagai penelitian dasar bagi penelitian keperawatan selanjutnya yang berkaitan dengan tidur pasien di rumah sakit, seperti mengenai faktorfaktor yang memengaruhi tidur pasien rawat inap di rumah sakit terkait karakteristik demografi pasien, serta angka kejadian berbagai jenis gangguan tidur pada pasien rawat inap di rumah sakit. Penelitian ini juga dapat menjadi rencana edukasi dan terapi dengan tujuan untuk meningkatkan kualitas dan kuantitas tidur pasien rawat inap, salah satunya dengan modifikasi lingkungan, mengajarkan teknik relaksasi dan pijat, serta kolaborasi dengan pihak manajemen sarana dan prasarana di RS X Depok untuk menyediakan AC di ruang rawat inap dan TV (MR, YU, AR).

\section{Referensi}

Benca, R.M., \& Quintans, J. (1997). Sleep and host defenses: A review. Sleep, 20 (11), 10271037. 
Crisp, J. \& Tailor, C. (2001). Potter and perry's fundamentals of nursing. Sidney: Mosby.

DeLaune, S.C., \& Ladner, P.K. (2011). Fundamentals of nursing: Standards \& practice. (4th Ed.). USA: Thomson Learning, Inc.

Doering, L.V., McGuire, A.W., \& Rourke, D. (2002). Recovering from cardiac surgery: What patients want you to know. American Journal of Critical Care, 11 (4), 333-343.

Humphries, J.D. (2008). Sleep disruption in hospitalized adults. Medsurg Nursing, 17 (6), 391-395.

Meerlo, P., Sgoifo, A., \& Suchecki, D. (2008). Restricted and disrupted sleep: Effects on autonomic function, neuroendocrine stress systems and stress responsivity. Sleep Medicine Reviews, 12 (3), 197-210.

Patel, M., Chipman, J., Carlin, B., \& Shade, D. (2008). Sleep in the intensive care unit setting. Critical Care Nursing Quarterly, 31, 309-318.
Patel, P., \& Gupta, R. (2008). Quality of sleep in hospitalized patients. Medicine and Health Rhode Island, 91 (11), 346-346.

Polit, D.F., \& Beck, C.T. (2008). Nursing research: generating and assessing evidence for nursing practice. (8th Ed.). Philadelphia: Lippincott Williams \& Wilkins.

Redeker, N.S., Ruggiero, J.S., \& Hedges, C. (2004). Sleep is related to physical function and emotional well-being after cardiac surgery. Nursing Research, 53 (3), 154-162.

Wright, C.E., Erblich, J., Valdimarsdottir, H.B., \& Bovbjerg, D.H. (2007). Poor sleep the night before an experimental stressor predicts reduced NK cell mobilization and slowed recovery in healthy women. Brain, Behavior, and Immunity, 21 (3), 358-363. 